\title{
Japanese fan flow
}

Schnipper, Teis; Tophøj, Laust Emil Hjerrild; Andersen, Anders Peter; Bohr, Tomas

Published in:

Physics of Fluids

Link to article, DOI:

$10.1063 / 1.3479926$

Publication date:

2010

Document Version

Publisher's PDF, also known as Version of record

Link back to DTU Orbit

Citation (APA):

Schnipper, T., Tophøj, L. E. H., Andersen, A. P., \& Bohr, T. (2010). Japanese fan flow. Physics of Fluids, 22(9), 091102. https://doi.org/10.1063/1.3479926

\section{General rights}

Copyright and moral rights for the publications made accessible in the public portal are retained by the authors and/or other copyright owners and it is a condition of accessing publications that users recognise and abide by the legal requirements associated with these rights.

- Users may download and print one copy of any publication from the public portal for the purpose of private study or research.

- You may not further distribute the material or use it for any profit-making activity or commercial gain

- You may freely distribute the URL identifying the publication in the public portal

If you believe that this document breaches copyright please contact us providing details, and we will remove access to the work immediately and investigate your claim 


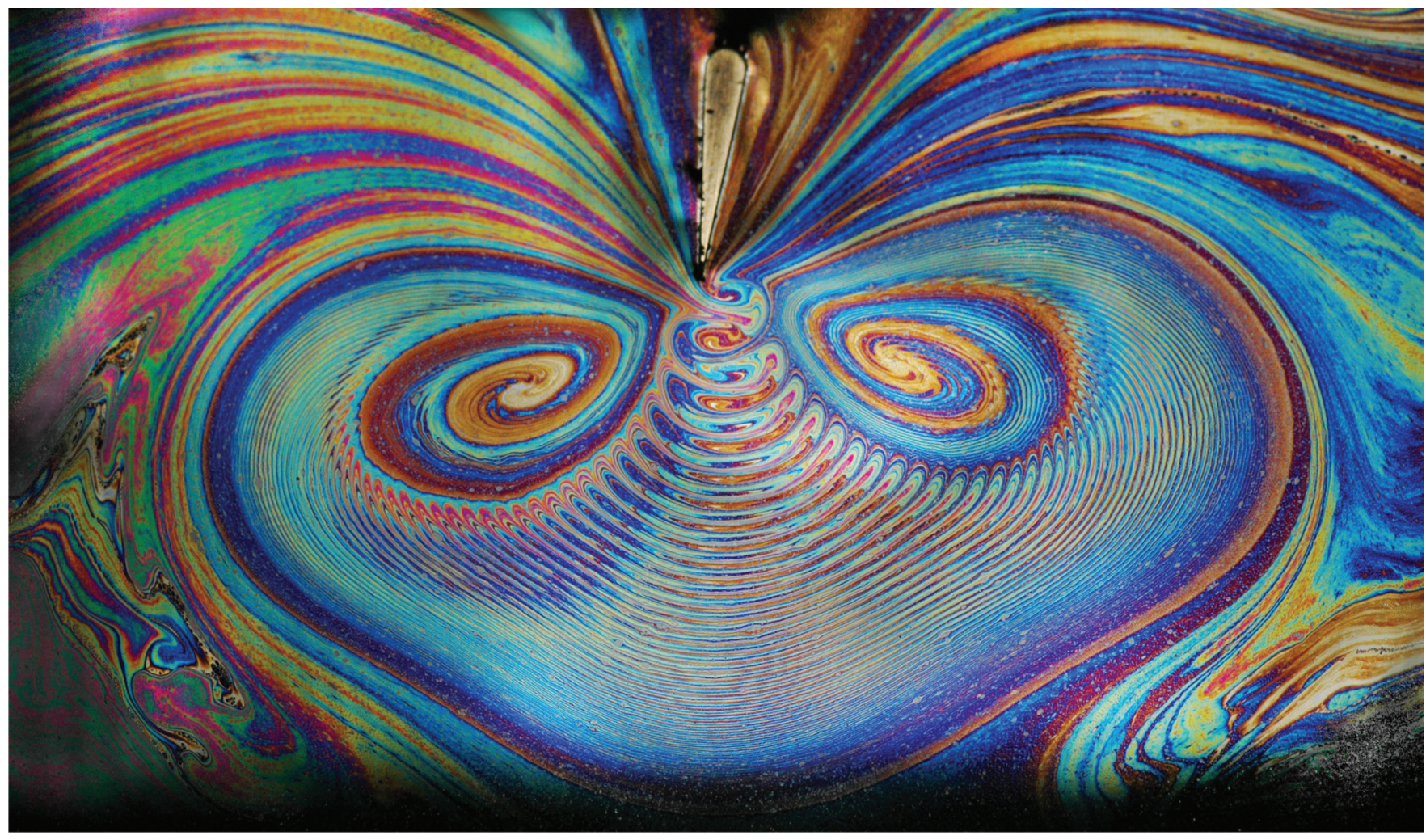

FIG. 1. (Color)

\section{Japanese fan flow}

Teis Schnipper, Laust Tophøj, Anders Andersen, and Tomas Bohr

Department of Physics and Center for Fluid Dynamics, Technical University of Denmark, DK-2800 Kgs. Lyngby, Denmark

(Received 6 July 2010; published online 30 September 2010) [doi:10.1063/1.3479926]

The Japanese geishas are famous for using decorated flapping fans to create a cooling breeze on warm summers days. In Fig. 1, we show the complex flow caused by a two-dimensional "fan": A rapidly pitching foil in an otherwise stationary and horizontal soap film. The colorful patterns stemming from thickness variations visualize the streaming clearly seen in the stripes on both sides of the foil (top center). Two vortical structures are formed at the tip in each oscillation period. These structures are advected downstream, while being stretched in the lateral direction and compressed in the streamwise direction. The pattern is a hitherto unknown example of a flow structure due to unsteady formation of separation vortices. ${ }^{1}$ In contrast to the periodic vortex wake shed behind a similar pitching foil in a streaming soap film, ${ }^{2}$ the fan flow forms a broadening layered pattern, which merges into two beautiful spiral rolls, giving the whole flow a butterfly shape. Take a look at the foil and follow the vortex pattern on one side-the row of vortices can be discerned all the way into the spiral, as footprints of the fan motion of the past.

The rigid foil is $12 \mathrm{~mm}$ long, $2 \mathrm{~mm}$ wide, and it is driven with simple harmonic pitching oscillations around the center of the semicircular leading edge at a frequency of $100 \mathrm{~Hz}$ and a lateral tip excursion of $1.5 \mathrm{~mm}$. The fluid is a commercial soap bubble mixture, consisting of demineralized water, $5 \%$ Fairy Ultra detergent, 5\% glycerin, $0.16 \%$ hydroxyethyl cellulose, $1.0 \%$ lauramidopropyl betaine, $0.80 \%$ propylene glucol, and $0.20 \%$ peg- 80 sorbitan laurate. We speculate that non-Newtonian effects play a role in the pattern formation.

\footnotetext{
${ }^{1}$ A. Andersen, T. Bohr, and T. Schnipper, "Separation vortices and pattern formation," Theor. Comput. Fluid Dyn. 24, 329 (2010).

${ }^{2}$ T. Schnipper, A. Andersen, and T. Bohr, "Vortex wakes of a flapping foil," J. Fluid Mech. 633, 411 (2009).
} 